\title{
Conjunctival Carcinoma cM0 TNM Finding v8
}

National Cancer Institute

\section{Source}

National Cancer Institute. Conjunctival Carcinoma cM0 TNM Finding v8. NCI Thesaurus. Code C140530.

Conjunctival carcinoma with no distant metastasis. (from AJCC 8th Ed.) 